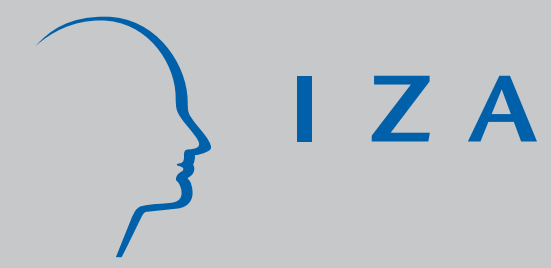

IZA DP No. 61

Immigration: The New Zealand Experience

Rainer Winkelmann

October 1999 


\title{
IMMIGRATION: THE NEW ZEALAND EXPERIENCE
}

\author{
Rainer Winkelmann \\ University of Canterbury \\ Christchurch, New Zealand
}

\section{Discussion Paper No. 61 October 1999}

\author{
IZA \\ P.O. Box 7240 \\ D-53072 Bonn \\ Germany \\ Tel.: +49-228-3894-0 \\ Fax: +49-228-3894-210 \\ Email: iza@iza.org
}

This Discussion Paper is issued within the framework of IZA's research area General Labor Economics. Any opinions expressed here are those of the author(s) and not those of the institute. Research disseminated by IZA may include views on policy, but the institute itself takes no institutional policy positions.

The Institute for the Study of Labor (IZA) in Bonn is a local and virtual international research center and a place of communication between science, politics and business. IZA is an independent, nonprofit limited liability company (Gesellschaft mit beschränkter Haftung) supported by the Deutsche Post AG. The center is associated with the University of Bonn and offers a stimulating research environment through its research networks, research support, and visitors and doctoral programs. IZA engages in (i) original and internationally competitive research in all fields of labor economics, (ii) development of policy concepts, and (iii) dissemination of research results and concepts to the interested public. The current research program deals with (1) mobility and flexibility of labor markets, (2) internationalization of labor markets and European integration, (3) the welfare state and labor markets, (4) labor markets in transition, (5) the future of work, (6) project evaluation and (7) general labor economics.

IZA Discussion Papers often represent preliminary work and are circulated to encourage discussion. Citation of such a paper should account for its provisional character. 


\section{ABSTRACT}

\section{Immigration: The New Zealand Experience}

A history of the New Zealand immigration experience and policy is reviewed in this paper. Data from the 1981 and 1996 New Zealand Censuses are used to illustrate changes in the characteristics of immigrants, as well as labor outcomes. The decline in the income of recent immigrants over the period studied is found mainly to be due to changes in the region-oforigin composition. Immigrants are found to have lower income than natives upon arrival. However, income parity is reached after 20-30 years of residence. Immigrants with English speaking background do substantially better in the New Zealand labor market, relative to migrants with non-English speaking background.

JEL Classification: J15, J61, J68

Keywords: Immigration, labor outcomes, Assimilation

Rainer Winkelmann

University of Canterbury

Department of Economics

Private Bag 4800

Christchurch, New Zealand

Fax: 64-3-3642635

Email: r.winkelmann@econ.canterbury.ac.nz 


\section{Introduction}

The stagnation of real wages and rising unemployment rates for many types of workers since the late 1970s have led governments around the world to adopt policies to increase worker education. The policies came hand in hand with arguments emphasizing the adverse role that the alleged relative decline in immigrant/native education levels has played in generating those outcomes and the rising income inequality more generally. Governments in many countries responded by changing their immigration policies in order to improve national welfare and growth.

New Zealand is a prime example. Traditionally an immigration country, it swiftly changed the focus of its immigration policy towards a general- and/or occupational skills principle as the arguments about an increasing demand for "skilled" workers began to emerge. Concerns that skilled workers migrate out - causing "brain drain" - not withstanding, the arguments often included a reference to desirable distributional effects of "skilled" immigration and the idea that immigrants who have skills that are in high demand adapt rapidly to conditions in the domestic labor market and are more likely to make a significant contribution to economic growth.

These changes in policy away from a country-of-origin principle that was characteristic of the first half of the century have been accompanied by substantial shifts in the composition of immigrants. While the initial immigrants came predominantly from the United Kingdom, flows started to diversify after World War II. The 1960s and 1970s brought a wave of immigrants from the Pacific Islands, while the late 1980s and early 1990s saw a jump in the number of immigrants from Asia. The consequences of the resulting changes in the size and composition of immigration are controversial in academic and policy circles alike.

The objective of this article is to shed some light on the relative importance of education on one hand and race and ethnicity on the other hand in explaining the relative labor market performance of immigrants. The article describes New Zealand's current immigrant population against the background of its immigration history (Section 2), characterizes the country's current policies (Section 3), and analyses the labour 
market outcomes of New Zealand's immigrants (Section 4). Section 5 concludes by pointing out some potential lessons of New Zealand's experience for Europe.

\section{The History of Immigration to New Zealand ${ }^{1}$}

\subsection{The first century of European immigration}

New Zealand was first settled by Maori, who arrived by canoe between 750 and 1350 AD from various eastern Polynesian Islands. The first European contact was made in the late $18^{\text {th }}$ century at a time when the Maori population was estimated around $100,000 .^{2}$ In 1840 when the Treaty of Waitangi established British sovereignty over the country, the number of European Settlers did not exceed 2,000, whereas the Maori population had decreased to between 70,000-90,000. A systematic colonisation by British migrants followed, and by the mid-1850s the European population was as large as the Maori one, and outgrew the Maori population fast thereafter. Between 1871 and 1892 alone, almost 114,000 people immigrated under an assisted immigration scheme resulting from the Immigration and Public Works Act of 1870, and the total population had reached 700,000 in 1892 (New Zealand Official Yearbook 1995, p. 40).

The large and steady inflow of migrants continued well into the 1900s. Immigrants had mostly British and Irish background, encouraged by a principle of free entry and assisted migration. ${ }^{3}$ Since the late 1800 s, New Zealand had actively restricted immigration from Asian (as well as Southern European) countries, and their numbers remained relatively low until the second half of the $20^{\text {th }}$ century. Assisted migration was terminated after the Great Depression (by the time of which the New Zealand

1 This section draws on Shroff (1988) and New Zealand Immigration Service (1997) where more details on New Zealand's immigration history can be found. Another source is Burke (1986). Summaries of empirical trends in gross and net migration data over the last few decades, together with some analysis, are given in Trlin and Spoonley $(1986,1992,1997)$.

2 New Zealand (or, in Maori, Aotearoa) was sighted by Dutch navigator Abel Tasman in 1642, but it was a further 127 years, in 1769, before British naval captain James Cook and his crew became the first Europeans to set foot on New Zealand soil.

3 Formal independence from the United Kingdom was gained on September 26, 1907. 
population counted about 1.5 million) and was not re-instated for some time. As a consequence, immigration during the post-Depression years was limited, and a period of net-migration losses continued until after the end of World War II. ${ }^{4}$

\subsection{The 1950s and 1960s}

In 1947 the Government decided to reintroduce an assisted passage scheme, mostly for immigrants from the British Isles. In 1951, the Netherlands Migration Scheme was established as a bilateral assisted immigration scheme between the governments of the Netherlands and New Zealand. Both programs targeted specific skills and occupations in high demand in New Zealand. Some provisions for family based migration were made.

The effects of these programs can be clearly seen from Figure 1, where the annual permanent and long-term net-migration is plotted from 1946 to 1998. These numbers give the excess of arrivals of people intending to stay in New Zealand permanently or for 12 months or longer over the number of people departing permanently or for 12 months or longer (including New Zealanders). ${ }^{5}$ It is apparent that net-migration picked up gradually after 1947, eventually exceeding 20,000 in 1953 . The net-migration gain remained relatively stable at between 10 and 20 thousand per year throughout the 1950s and for most of the 1960s. Nevertheless, these annual flows constituted less than 1 percent of the population at the time, and immigration had

Source: New Zealand Immigration Service (1997). 1946-1969 are March years, 1970-1996 are calendar years, and 1997 and 1998 are November years.

\footnotetext{
$4 \quad$ New Zealand received only very small numbers of refugees from fascism or World War II.

5 As New Zealand is an island nation, it has full control over its external borders and thus the statistics should be quite accurate. Nevertheless, net permanent and long-term migration is a less than ideal measure of immigration trends as it does not distinguish between returning citizens, foreign nationals on temporary visa (including, for instance, students) and genuine immigrants. Also, outmigration was always an important factor in New Zealand and fluctuated substantially over the period.
} 
Figure 1: New Zealand Permanent and Long-Term Net-Migration 1946-1998

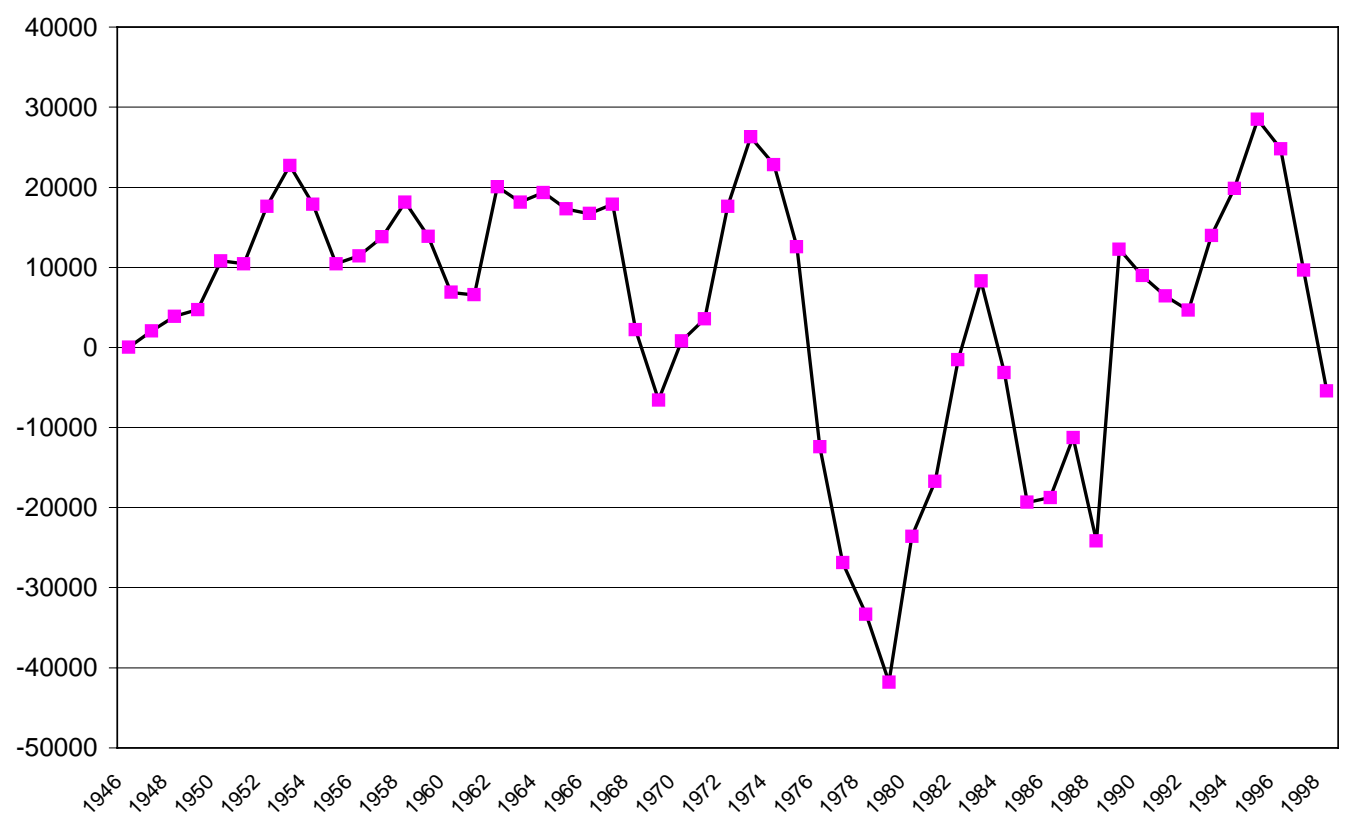

become a relatively small component of New Zealand's population growth compared with the early years of colonization.

The hallmark of the late 1950s and the early and mid-1960s was the emergence of truly diversified migration. For the first time, migrants of British and Irish origin no longer made up more than half of the permanent and long-term arrivals. This changing trend was also reflected in the country-of-origin composition of the New Zealand resident population as evident in Census data, although the changes were slow initially. In the three Census years 1945, 1956 and 1966, the share of the population born outside of New Zealand varied between 14 and 15 percent. However, as shown in Table 1, the proportion of British and Australian born residents among the overseas born declined by more than 10 percentage points, from 88.8 percent in 1945 to 77.7 percent in 1966 . They were gradually replaced by immigrants from the Netherlands, the Pacific Islands, and, at this stage to a lesser extent, from Asia. 
Table 1. New Zealand's Changing Population Structure, 1945-1966.

\begin{tabular}{lccc}
\hline Census Year & 1945 & 1956 & 1966 \\
& & & \\
Overseas born as \% of total & 14.5 & 14.3 & 14.8 \\
population & & & \\
& & & \\
Country of Origin as \% of & & & \\
overseas born population & & & \\
UK and Ireland & 73.9 & 69.1 & 66.8 \\
Australia & 14.9 & 11.6 & 10.9 \\
Netherlands & 0.1 & 4.0 & 5.2 \\
Pacific Islands & 1.1 & 2.8 & 5.5 \\
India & 0.9 & 1.4 & 1.4 \\
China (P.R.) & 1.3 & 1.2 & 1.1 \\
\hline
\end{tabular}

Source: NZ Official Yearbook, various issues.

\subsection{The 1970s and 1980s}

The 1970s and 1980s were turbulent times for immigration. The ups and downs in net migration flows (see Figure 1) were the result of both cyclical policy decisions and lower transport costs that made outmigration rates more volatile and sensitive to economic conditions. A typical policy cycle would consist in a promotion of immigration during times of labour market shortages. The associated delays between recruitment and arrival of immigrants would mean that immigrants arrived during less favourable conditions, producing hostile attitudes in the population and a subsequent restriction of immigration.

The beginning of the 1970s saw the start of such a cycle, with intensive efforts to attract more immigrants via subsidised immigration schemes, a widening of the eligibility by source country (to most Western European states and the United States), and an intensive marketing campaign. At the time, agricultural prices were booming, 
New Zealand had virtually zero unemployment and ranked about $10^{\text {th }}$ in the world in GDP per capita (New Zealand Official Yearbook, 1995, p. 40). Permanent and longterm arrivals peaked at 70,000 in 1973/74, the year of the first oil price shock. In addition to the adverse economic conditions, the sheer size of the inflow meant immense pressure on housing and schools and other services. Not surprisingly, brakes were put on soon. British ceased to be granted unrestricted access in April of 1974. ${ }^{6}$ The general assisted schemes were abolished in 1975 and the Dutch scheme in 1976.

The other feature of the period was the continued trend towards more diversified immigration, a further shift towards immigrants from "non-traditional" source countries, mostly the Pacific Islands. In 1976, occupational migration had been officially opened to a yet wider range of source countries although an explicit non-discriminatory immigration policy without regard for national or ethnic origin was adopted only a decade later. It was also in 1976 that a large number of Pacific Island de-facto immigrants who had come to New Zealand with temporary work permits and overstayed gained residence status by way of general amnesty.

The effects of these changing migration flows on the composition of the New Zealand population are studied in the next table. The table is adopted from Winkelmann and Winkelmann (1999). Data are from the Population Census and relate to the working age population (those aged 15-64). At the 1981 Census day, for instance, about 320 thousand working-age immigrants lived in New Zealand. ${ }^{7}$ This amounted to 16.2 percent of the total working age population. Among those immigrants, 12.1 percent had arrived in the five-year period preceding the Census, i.e., between 1976 and 1980.

\footnotetext{
6 Coincidence or not, this was one year after Britain had joined the European Economic Community.

7 The Census is held at the end of February or beginning of March of the year. The definition of "immigrant" in the Census includes all people who were born overseas and resided in New Zealand on Census day, independently of their official visa status (temporary or permanent residence, citizenship, etc.).
} 


\section{Table 2: New Zealand's Working Age Immigrant Composition by Region of Origin, 1981 and 1986}

\begin{tabular}{lcrrrrrrr}
\hline & \multicolumn{4}{c}{ 1981 Census } & \multicolumn{7}{c}{ 1986 Census } \\
& \multicolumn{1}{c}{ All Immigrants } & \multicolumn{1}{c}{$1976-80$ Cohort } & \multicolumn{2}{c}{ All Immigrants } & \multicolumn{1}{c}{$1981-85$ Cohort } \\
& $\mathrm{N}$ & \multicolumn{1}{c}{$\%$} & $\mathrm{~N}$ & $\%$ & $\mathrm{~N}$ & $\%$ & $\mathrm{~N}$ & $\%$ \\
\hline & & & & & & & & \\
UK \& Ireland & 179825 & 56.37 & 12020 & 31.12 & 178805 & 52.47 & 12325 & 27.52 \\
Australia & 27487 & 8.62 & 5527 & 14.31 & 29189 & 8.56 & 4717 & 10.53 \\
Europe \& Nth & 42954 & 13.46 & 5956 & 15.42 & 47042 & 13.80 & 8140 & 18.17 \\
America & & & & & & & & \\
Pacific Islands & 41644 & 13.05 & 7340 & 19.00 & 52253 & 15.33 & 9887 & 22.08 \\
Asia & 18831 & 5.90 & 6141 & 15.90 & 24446 & 7.17 & 8133 & 18.16 \\
Other & 8295 & 2.60 & 1638 & 4.24 & 9072 & 2.66 & 1585 & 3.54 \\
& & & & & & & & \\
Total & 319036 & 100.00 & 38622 & 100.00 & 340807 & 100.00 & 44787 & 100.00 \\
\hline
\end{tabular}

Source: Winkelmann and Winkelmann (1999).

In 1981, 56 percent of working age immigrants were born in the UK or Ireland. This was a substantial reduction relative to the 67 percent (in terms of the overall population) still observed in the 1966 Census. The main beneficiaries of the diversification were Europe\&North America and the Pacific Islands, with a share of about 13 percent each (among working age immigrants). The Asian share remained at 6 percent, although Asian immigration definitely started to pick up at the time, as Asians constituted 16 percent of all recent immigrants who had arrived in the second half of the 1970s.

The trend towards increased diversity continued to be a strong force in the $1980 \mathrm{~s}$ (and ever since). Among all persons who migrated to New Zealand between 1981 and 1985 and remained in the country until Census day, only 28 percent came from the British Isles, and the number of UK and Irish-born persons resident in New Zealand as a proportion of all working-age immigrants had decreased to just over half. By 1990, the percentage of migrants from the United Kingdom had fallen to 16 percent (New Zealand Immigration Service, 1997). British migrants were increasingly replaced by 
Pacific Island and Asian nationals. In 1986, for instance, 22 percent of recent immigrants originated from the Pacific Islands, and 18 percent from Asia (see Table 2). By 1990, countries such as Hong Kong, Taiwan and Malaysia had become major sources of immigration to New Zealand.

\subsection{The 1990s}

In terms of policy events, the changes of the 1990s were foreshadowed by the passing of the Immigration Act 1987 (by the then Labour government) that heralded a substantial re-orientation of policy. This Act was superseded by the Immigration Amendment Act 1991 (under a National government) in which the current point system was established. Details of the policy changes are discussed in the next section. At this point, it suffices to say that the Acts promoted a further diversification of immigration flows by countryof-origin both directly and indirectly, and sought to establish and promote explicit channels for migration based on business and investment motives. Furthermore, the 1991 Act terminated the long-standing tradition of linking immigration to skill shortages and priority occupations, as the point system rewards professional experience and formal qualifications of any type. It also introduced an explicit annual target of initially 25,000 approvals.

The more open and flexible immigration policies had a substantial impact on the number of immigrants. This is most clearly seen in the number of annual residence approvals that are published by the New Zealand Immigration Service for more recent years (New Zealand Immigration Service, 1997). ${ }^{8}$ Between 1982 and 1987, the number of annual approvals was around 10,000 per year. In 1988, approvals jumped to over 25,000 and remained there until 1994, when another increase to 43,000 occurred. In 1995 the approvals numbered 56,260, and in 1996 42,729 applications were approved.

In New Zealand, citizenship can be obtained after 3 years of residence. Permanent residents have most citizen rights including vote. 
In combination with fewer than normal permanent and long-term departures, the netmigration gain in the mid 1990s was substantial (see Figure 1). ${ }^{9}$

As seen before in New Zealand's history, this large immigration wave, and the resulting pressure on urban centers, and a housing crisis in Auckland in particular, put migration back on the popular political agenda. ${ }^{10}$ A 1995 policy review affected immigration in two ways. First, the selection criteria were changed (in particular with respect to English language proficiency), and secondly, the targeted number of new migrants that had in the meantime climbed up to 48,000 and 55,000, was lowered to 35,000 for the 1996/97 June year. Immigration flows proved to be responsive to the policy changes, and the number of approvals declined to 33,683 new immigrants in the year ended June 1997. This declining trend continued into 1998, bringing down the netgains in permanent and long-term migration, from 24,793 in 1996 to 9,650 in 1997 and -5,460 in 1998 (Figures for 1997 and 1998 are for years ending November). As the government is aiming for an average migration gain of 10,000 people per year a policy review followed in 1998 and some parameters were adjusted in order to "attract more skilled migrants to New Zealand" (The Press, 3 June 1998).

The 1994-1996 immigration boom was controversial not only for its sheer magnitude, but also because of its composition. The top ten-countries of approvals among the main categories in 1996 included Taiwan (12\%), China (12\%), India (8\%), South Korea (5\%), Hong Kong (4\%) and the Philippines (3\%). In the 1996 Census, the proportion of Asians had increased to 21 percent of all, and to 47 percent of recently arrived (1991-95) foreign-born residents.

9 Note, though, that successful applicants do not necessarily enter New Zealand in the year they are granted residence, and there is some evidence that this effect may be of quantitative importance (Bedford, 1996).

10 In 1996, 31 percent of all people living in Auckland were foreign-born. See Winkelmann and Winkelmann (1998). 


\subsection{Summary and implications for current policy}

After the large inflows of the early colonization years, immigration, though still high by world standards, slowed down. In more recent decades, the composition of immigrants shifted away from "traditional source" countries such as Great Britain towards neighbor countries (and trading partners) in the Pacific Islands and Asia. Today, New Zealand remains, with a land area similar to that of Colorado or the United Kingdom and a population of 3.8 million, a sparsely populated country.

Between 1946 and 1998, the overall population grew by 2.2 million. During this period, the population gain through permanent and long-term migration was only 258,911 persons, or 12.3 percent of the total population growth. Nevertheless, it would be wrong to conclude that New Zealand had developed a hostile attitude towards immigration, or suffered from its remote location at the periphery of the world. While elements of xenophobia have been identified in the past (see, for instance, Shroff, 1995), the policies of the last decade have been consistently pro-immigration. As a consequence, annual immigration flows have remained above 1 percent of the population since 1988, reaching 1.6 percent in 1995 . This is well above the rates for other traditional immigration countries such as Australia (0.5 percent), Canada (0.8 percent) or the United States (0.3 percent). ${ }^{11}$

New Zealand's problem was the very high rate of emigration. Therefore, the neteffect of external migration on New Zealand's population remained minor during the post-WWII period. The emigration rate was also very volatile. Therefore, the optimal immigration rate that would lead to a stable population growth without any undue pressures on infrastructure and social cohesion is very difficult (or impossible) to determine. The factors that make people emigrate have received little attention so far (one exception being Brosnan and Poot, 1987). In the case of previous immigrants returning to their country of origin, the lack of any settlement policy (provisions of post-

11 In 1997, the Australian Prime Minister John Howard announced a reduction in the immigration intake to 68,000, compared to a targeted intake in New Zealand, a country one fifth in population size, of 38,000 . 
arrival services intended to ease the integration of new immigrants) may be one such factor that is currently under review in policy circles.

\section{Current residence policy}

\subsection{The changing policy context}

The two key immigration policy events during recent years were the passing of the Immigration Act 1987 and the Immigration Amendment Act 1991. Pre-1987, immigration was subject both to an occupational priority list and to a preferred source country list. ${ }^{12}$ A comprehensive review the New Zealand's immigration policy was conducted in 1986. Factors motivating this review included a desire to acknowledge New Zealand's location in the Asia-Pacific region (factors being that immigration from within this region might foster trade, attract investment, and increase cultural diversity), and a desire to tidy up some of the administrative and legal shortcomings of the old legislation (Burke, 1986).

Consequently, the Immigration Act 1987 did away with the "traditional source" preference for UK, Western European and North American nationals. It rationalised the system of an occupational priority list in order to encourage the immigration of people with skills for which excess demand in New Zealand could be identified. Residence applications made on occupational grounds required a firm employment offer and were based on personal merit (with the exception of some bilateral preferential access arrangements with Australia, the Netherlands, and Western Samoa). Family reunification immigration continued.

12 An occupational priority list (OPL) was in existence from the mid 1960s. In order to employ immigrants without OPL skills, the employer had to demonstrate that no suitable New Zealand resident was available. After 1976, the employment of immigrants from "non-traditional" source countries with OPL skills became possible, provided their skills were not in demand in their home country and it was not possible to obtain migrants from preferred sources (New Zealand Immigration Service, 1997). 
The Immigration Amendment Act 1991 went a significant step further by replacing the occupational priority list with a point system, attempting to increase New Zealand's stock of general human capital rather than using residency policy as a shortterm labour market tool. The requirement of a job offer was abandoned, although a job offer increases an applicant's point score. A soft immigration target of 25,000 was introduced, but it was exceeded substantially after 1993, peaking at 56,000 residency approvals in 1995 (about 72 percent of which were approved under the General Skills Category).

In October 1995, rules were tightened somewhat. For example, the minimum English language requirements was extended from just the principal applicant to all adult family members in both the General Skills and the Business Investor categories. In occupations where professional registration is required by law in New Zealand (such as for physicians, lawyers, and electricians), the registration must be obtained before points for these qualifications can be awarded. In addition, the tax treatment of investments by immigrants was changed.

As far as long-term migration is concerned, it appears that the introduction of the point system in 1991 was instrumental in encouraging diversified immigration, and Asian immigration in particular. Whether the policy was successful, in the sense of attracting individuals with high human capital who will succeed in the New Zealand labour market, is an issue that will be considered below.

\subsection{The point system}

The 1991 Immigration Amendment Act established four main categories for obtaining permanent residence in New Zealand (in addition to refugee status). These were the General (in 1995 renamed to General Skills), Business Investment (in 1995 renamed to Business Investor), Family and Humanitarian categories. In 1996, 61 percent of all approvals came from the General Skills category, 25 percent from the Family category, and 4 percent from Business Investments. The exact proportions vary from year to year. But unlike for other countries, including Australia, Family re-unification (for parent, siblings, dependent children, and partners) is not the major constituent part of current 
migration. The majority of immigrants come to New Zealand through the General Skills category and are thus directly subject to the selection criteria reflected in the point system.

The following Table 3 lists the elements of the points system after the October 1995 policy changes. The pass mark to gain residence stayed at 25 points over most of the period.

Table 3: Summary of Points Scored in General Skills Category

\section{Qualifications}

\begin{tabular}{|c|c|}
\hline Base qualification & 10 \\
\hline Advanced qualification & 11 \\
\hline Master degree or higher & 12 \\
\hline \multicolumn{2}{|l|}{ Employability } \\
\hline \multicolumn{2}{|l|}{ Work Experience } \\
\hline 2 years & 1 \\
\hline 4 years & 2 \\
\hline 6 years & 3 \\
\hline 8 years & 4 \\
\hline 10 years & 5 \\
\hline 12 years & 6 \\
\hline 14 years & 7 \\
\hline 16 years & 8 \\
\hline 18 years & 9 \\
\hline 20 years & 10 \\
\hline Offer of Employment & 5 \\
\hline \multicolumn{2}{|l|}{ Age } \\
\hline 18-24 years & 8 \\
\hline 25-29 years & 10 \\
\hline 30-34 years & 8 \\
\hline 18-39 years & 6 \\
\hline 18-44 years & 4 \\
\hline
\end{tabular}


18-49 years

Maximum Age: 55 years

\section{Settlement Factors}

\begin{tabular}{ll}
\hline $\begin{array}{l}\text { Settlement funds } \\
\$ 100,000\end{array}$ & 1 \\
$\quad 200,000$ & 2 \\
Partner's qualification & 1 \\
$\quad$ Base qualification & 2 \\
$\quad$ Advanced qualification & 1 \\
New Zealand work experience & 2 \\
1 year & 3 \\
2 years & 7 \\
Family Sponsorship & \\
Maximum settlement points &
\end{tabular}

The relative "prices" for immigrants attributes have to following characteristics: First, there is an offsetting effect of age and experience. Some simple calculations help to illustrate the nature of the trade-off. Assume that an applicant had an uninterrupted working career. In this case someone who started to work at the age of 18 obtains a maximum of 16 points for age and experience if aged 29-39 at the time of the application. For a starting age of 20 years, 16 points are reached for those aged 39 on application. If the applicant started to work at the age of 25 , the maximum achievable number of points is 14 when aged 44. Despite the step-wise nature of the system, a general pattern emerges: In general, it is better to have started the working career at an early age. The prime-age range is between 30 and 45. And the optimal age is an increasing function of age at entry into the labour market.

Second, a minimum base qualification is not necessary to get over the pass mark if an offer of employment exists. In this case, 21 points can be score from the employability factors, and the difference between 25 and 21 can be filled by settlement points. However, if settlements factors do not apply, then both a qualification and, in most cases, an offer of employment will be necessary to gain entry into New Zealand. 
Finally, the "returns" to a qualification beyond the base qualification are not very high (or even negative, if other factors are taken into account). In general, a Ph.D. will be worse off than a Bachelor because the years spent as a student do not qualify as work experience.

In practice, potential migrants can compute their point score prior to application on their own. If the current pass mark is reached, an applicant can be certain to be granted residence, subject to common health and character requirements. At the time of this writing, the application fee was NZ\$700 (approx. US\$400), and a settlement fee of NZ\$180 per person (NZ\$720 maximum per family) was payable upon arrival in New Zealand.

\subsection{Other entry categories and preferential arrangements}

Throughout the period New Zealand had provisions for temporary entry as visitors (up to 9 months), students (up to 4 years) or temporary workers (up to 3 years). As of 31 July 1996, there were 11,600 overseas students in New Zealand attending universities, polytechnics or schools. With several thousand each the two most numerous groups of temporary workers were fishing crew members and young people on working holidays undertaking casual work, such as fruit picking (New Zealand Immigration Service, 1997).

Special entry provisions exist for Australian citizens who have practically unrestricted access. New Zealand citizenship is automatically granted for inhabitants of three islands in the Pacific, Niue, Tokelau, and the Cook Islands who have a combined population of little over 20,000. Citizens of Samoa can apply for residence under a special quota of 1,100 permits a year if they are aged between 18 and 45 and have an offer of full-time permanent employment. Finally, New Zealand has established an annual quota of up to 800 refugees that is managed in co-operation with the United Nations High Commissioner of Refugees. 


\section{The labour market outcomes of immigrants}

\subsection{New Zealand research}

General reviews of the research issues with special reference to New Zealand are given in Maani (1991), Chapple, Gorby and Yeabsley (1994) and Chapple and Yeabsley (1996). A number of studies have analysed the determinants of migration flows (immigration or net-migration) to New Zealand using time series techniques. Among them, Brosnan and Poot (1987) and Gorbey, James and Poot (1997) deal with TransTasman migration (i.e., net permanent and long-term migration between New Zealand and Australia), whereas Gani and Ward (1995) study the migration of highly skilled and professionally trained workers from Fiji to New Zealand. These studies generally find that migration is economically driven, as the real income differential has a significant impact on net-migration flows. Also, there is evidence for persistence, as current flows are significantly and positively related to previous flows.

Empirical research on the labour market outcomes of immigrants based on Census tabulations include Poot, Nana and Philpott (1988), Poot (1993a) and Zodgekar (1997). The Poot et al. (1988) book analyses the labour force status of recent immigrants in the 1981 Census, while Poot (1993a) and Zodgekar (1997) study the relative incomes of immigrants in the 1986 and 1991 Census, respectively.

Poot et al. show that in 1981 recent migrants from the UK, Australia and North America had labour market activity patterns that were relatively similar to those of the New Zealand born. By contrast, unemployment rates among recent immigrants from the Pacific Islands were several times higher than those of New Zealand-born workers and other immigrant groups. In order to explore the process of adjustment to the New Zealand labour market, the authors graphed age-standardised labour force participation and unemployment rates by length of residence for immigrants from the UK, Australia, and the Pacific Islands. 
It was found that the rates of unemployment among male immigrants from the UK and Australia were initially higher than those of New Zealand born males, but these rates declined to below New Zealand-born levels within three years of residence. Female unemployment rates for immigrants from Australia and the UK showed similar patterns of convergence to native rates within a few years. By contrast, immigrants born in the Pacific Islands appeared to take much longer to converge to the unemployment rates of the New Zealand born (up to 15 years).

Poot (1993) studied the median annual incomes of immigrants using data from the 1986 Census. Using tabulated data, he controlled for the effects of age, occupation, country-of-origin and years since migration (using 10 five year cohorts from 0 to 50 years). Overall, only Pacific Islanders behaved like typical migrants: they had a substantial income disadvantage upon entry, and a relatively steep years since migration-income profile. However, they did not reach parity with the income of New Zealand-born workers before 35 or 40 years in New Zealand. UK born immigrants typically outperformed New Zealand-born workers from the start (i.e. they did not have an initial entry disadvantage), while Australians were similar to New Zealand-born workers.

Zodgekar (1997) used 1991 Census data to analyse the socio-economic characteristics and relative incomes of immigrants. He found that immigrant men's average income was 7.3 percent above the average income of New Zealand-born men. Once he controlled for differences in the age and education distribution, this relative income advantage turned into a disadvantage of 3.9 percent. He noted that immigrants from traditional source countries such as the UK had much higher average incomes than immigrants from the Pacific Islands and Asia, even after including the controls. He proposed one possible explanation for the relative disadvantaged position of Pacific Island migrants, namely that many of them came in the early 1970's in response to a labour shortage in manufacturing, a sector that had downsized substantially by 1991.

A common methodological feature of this previous research is the use of aggregate data or cross-tabulations. One reason was the previous policy of Statistics 
New Zealand not to grant access to unit-level data for reasons of confidentiality. This restriction was gradually lifted over recent years, and Winkelmann and Winkelmann $(1998,1999)$ represent the first studies of New Zealand's immigration experience based on unit-level census data, using the years 1981, 1986, and 1996 as observation points. ${ }^{13}$ The following summary of immigrants' labour market outcomes over the previous 3040 years is based mainly on the original report (Winkelmann and Winkelmann, 1998) where more details can be found.

\subsection{A socio-economic profile of New Zealand's immigrants}

\section{The educational attainment of immigrants}

In post-war New Zealand, immigration policies have targeted, in one way or another, immigrants with skills, either occupational skills, or, more recently, broadly defined "general skills". New Zealand being a country with a relatively high proportion of unskilled workers, importing skilled workers could be interpreted as a relatively inexpensive (since public subsidies to education, if any, are paid for by other countries) and immediate way to overcome a relative shortage in skilled labour. In theory, this change in relative supplies could benefit both unskilled New Zealand-born persons and, in particular, owners of New Zealand's capital stock. The argument for skilled immigration has been reinforced by another, namely that skilled immigrants make a greater contribution to economic activity, and hence the living standards of New Zealanders, than unskilled immigrants.

Table 4 lists the distribution of highest qualification for immigrants, recent immigrants and New Zealand-born persons in 1981 and 1996. Judged by the evidence presented in this table, the policy was quite successful as immigrants had distinctively higher education levels than New Zealand-born persons.

13 The data comprised a 5 percent random sample of New Zealand-born working-age residents, a 20 percent random-sample of working-age persons born in the UK, and the full population of other immigrants. The 1991 Census was omitted as it contained no question on the year in which foreignborn residents first arrived in New Zealand. 
Table 4: Educational Attainment, New Zealanders, All Immigrants and Recent Immigrants, 1981 and 1996 (in percent)

\begin{tabular}{lcccc}
\hline & None & School & $\begin{array}{c}\text { Vocational } \\
1981\end{array}$ & University \\
All Immigrants & 45.8 & 25.9 & 20.5 & 6.2 \\
Recent & 37.2 & 28.6 & 19.5 & 11.6 \\
Immigrants & & & 16.9 & 3.6 \\
New Zealanders & 49.5 & 26.7 & 1996 & 15.5 \\
All Immigrants & 23.3 & 31.9 & 27.8 & 24.7 \\
Recent & 13.5 & 35.3 & 22.9 & 8.0 \\
Immigrants & & & & 26.1 \\
New Zealanders & 29.6 & 34.7 & & \\
\hline
\end{tabular}

Note: Recent immigrants arrived between 1991 and 1995. Source: Winkelmann and Winkelmann (1998).

The educational difference between immigrants and New Zealand-born persons was large: immigrants were about 30 percent more likely to have a post-school qualification than New Zealand-born persons in any of the Census years, while recent immigrants were between 40 and 50 percent more likely. In absolute terms, the gap in post-school qualifications between New Zealand-born persons and recent immigrants increased from 10 percentage points in 1981 to 14 percentage points in 1996. Moreover, relative to New Zealand-born persons with post-school qualifications, immigrants tended to have a higher proportion of university qualifications and a lower proportion of vocational qualifications. In 1981, for instance, about 37 percent of recent immigrants with a post-school qualification had a university qualification, compared to only 18 percent of New Zealand-born persons. By 1996, this proportion had increased to more than 50 percent for recent immigrants, but remained unchanged for New Zealand-born persons. 
Table 5 shows the age distribution for the three working age populations, all immigrants, recent immigrants, and New Zealand-born persons, for 1996. The average age of a New Zealander in the working age population was 36 years whereas the average age of an immigrant was 40 years. Of particular interest is the comparison of recent immigrants and New Zealand-born persons. It indicates how youthful immigrants are when they arrive, and hence how immigration affects the age distribution of New Zealand residents. $^{14}$

Table 5: 1996 Age Distribution of Working Age of Immigrants and New Zealandborn persons.

\begin{tabular}{llll}
\hline \multicolumn{3}{c}{ Immigrants } \\
\hline Age & All & Recent & NZ-born \\
\hline & & & \\
$15-24$ & 0.153 & 0.279 & 0.244 \\
$25-34$ & 0.225 & 0.323 & 0.243 \\
$35-44$ & 0.243 & 0.247 & 0.224 \\
$45-54$ & 0.217 & 0.107 & 0.170 \\
$55-64$ & 0.159 & 0.042 & 0.116 \\
& & & 36.1 \\
\hline
\end{tabular}

Note: Recent immigrants arrived between 1991 and 1995. Source: Winkelmann and Winkelmann (1998).

Recent immigrants were on average about 4 years younger than New Zealandborn persons. This is consistent with the analysis in Poot et al. (1988) who used

\footnotetext{
${ }^{14}$ The age distribution of all immigrants, by contrast, reflects both the distribution of age-at-arrival as well as the size of immigrant flows over time, and the two components cannot be separated.
} 
demographic projections of different immigration scenarios to show that an increase in net migration would tend to slow down the ageing of New Zealand's population.

\section{Parental and marital status}

Apart from age and education, parental status is one of the main determinants of labour market opportunities and outcomes, for women in particular.

Table 6: Parental and (de facto) Marital Status of Immigrants and New Zealandborn residents, 1996 (in percent).

\begin{tabular}{lccl}
\hline \multicolumn{3}{c}{ Parent } \\
\hline & Joint & Sole & Partner \\
All Immigrants & 40.9 & 4.7 & 71.1 \\
Recent Immigrants & 45.5 & 3.5 & 65.5 \\
New Zealanders & 33.9 & 6.8 & 60.0 \\
\hline
\end{tabular}

Note: Recent immigrants arrived between 1991 and 1995. Source: Winkelmann and Winkelmann (1998).

Table 6 gives the proportion of parents with dependent children, either joint or sole, among all individuals living in a family situation for $1996 .{ }^{15}$ Immigrants had a higher propensity to live with a partner than did New Zealanders. 34 percent of the New Zealand-born, and 41 percent of all immigrants, were joint parents while the incidence of sole parenthood was 7 and 5 percent, respectively. In other words, 17 percent of all New Zealand parents were sole parents, compared to 10 percent of all immigrant parents.

\footnotetext{
${ }^{15}$ A dependent child is here defined as any child under 16 years.
} 


\section{English language proficiency}

The 1996 Census included a question on language proficiency. ${ }^{16}$ Table 7 gives the proportion of working age immigrants who listed English as one of the languages they were able to "conduct an everyday conversation in", by region-of-origin: Western and Eastern Europe, Northeast, Southeast and South Asia, Pacific Islands and other countries. 92 percent of all immigrants from these regions living in New Zealand in 1996 "spoke English", based on the above definition.

\section{Table 7: Proportion of Immigrants Speaking English Proficiently, by Region-of-} Origin, 1996.

\begin{tabular}{lll}
\hline & Recent & All \\
\hline Western Europe & 0.982 & 0.984 \\
Eastern Europe & 0.871 & 0.914 \\
Northeast Asia & 0.653 & 0.679 \\
Southeast Asia & 0.837 & 0.878 \\
Southern Asia & 0.861 & 0.893 \\
Pacific Islands & 0.796 & 0.849 \\
Other & 0.968 & 0.991 \\
& & \\
\hline Total & 0.834 & 0.920 \\
\hline
\end{tabular}

Virtually all immigrants from Western Europe and all immigrants from other areas (including native English speakers such as US Americans and Canadians) spoke English. Recent immigrants from other regions had lower proficiecny rates. 35 percent of recent immigrants from Northeast Asia, and 20 percent of recent immigrants from the Pacific Islands stated that they were not able to conduct an everyday conversation in

\footnotetext{
${ }^{16}$ The exact question was: "In which language could you have a conversation about a lot of everyday things?" with options English; Maori; Samoan; NZ sign language; and other (please specify).
} 
English. The "non-speaking rates" of recent immigrants from other Asian regions and Eastern Europe varied between 13 and 16 percent.

\subsection{The Labour Market Status of Immigrants}

The main event in New Zealand's immigration history over the last decade was the shift in inflow composition away from the traditional source countries, the United Kindom and Ireland, towards immigration from Asia and the Pacific Islands. How did this change in supply affect the relative labour market outcomes of immigrants?

Before trying to answer this question, it is worthwhile remembering that demand factors were subject to change as well. During the initial three decades of the post-war period, New Zealand had been a country with virtually no unemployment. Unemployment rates remained below 1 percent of the labour force until 1978, when the unemployment rate increased to 2 percent. Five years later, unemployment reached 6 percent, and in the early 1990s, it was as high as 14 percent if based on register statistics (Dalziel and Lattimore, 1996). Also, a substantial restructuring of the economy took place as jobs in the service sector replaced those lost in manufacturing. Thus, immigrants arriving in New Zealand during the first half of the 1990s did face quite different labour market conditions upon entry compared to their peers who had arrived one or two decades earlier.

As Figure 2 shows, employment rates changed substantially between 1981 and 1996. The four panels plot employment rates (as a proportion of the working age population) for New Zealand-born persons, immigrants and recent immigrants by age, for men and women and the two Census years, respectively. For instance, the upper left panel is for men in 1981. The differences in employment rates between immigrants and New Zealand-born persons were not very large, except for young recent immigrants, which might be linked to their disproportionate participation in higher education. For all groups, mid-age employment rates were over 90 percent. 


\section{Figure 2: Age-employment profiles, men and women, 1981 and 1996.}
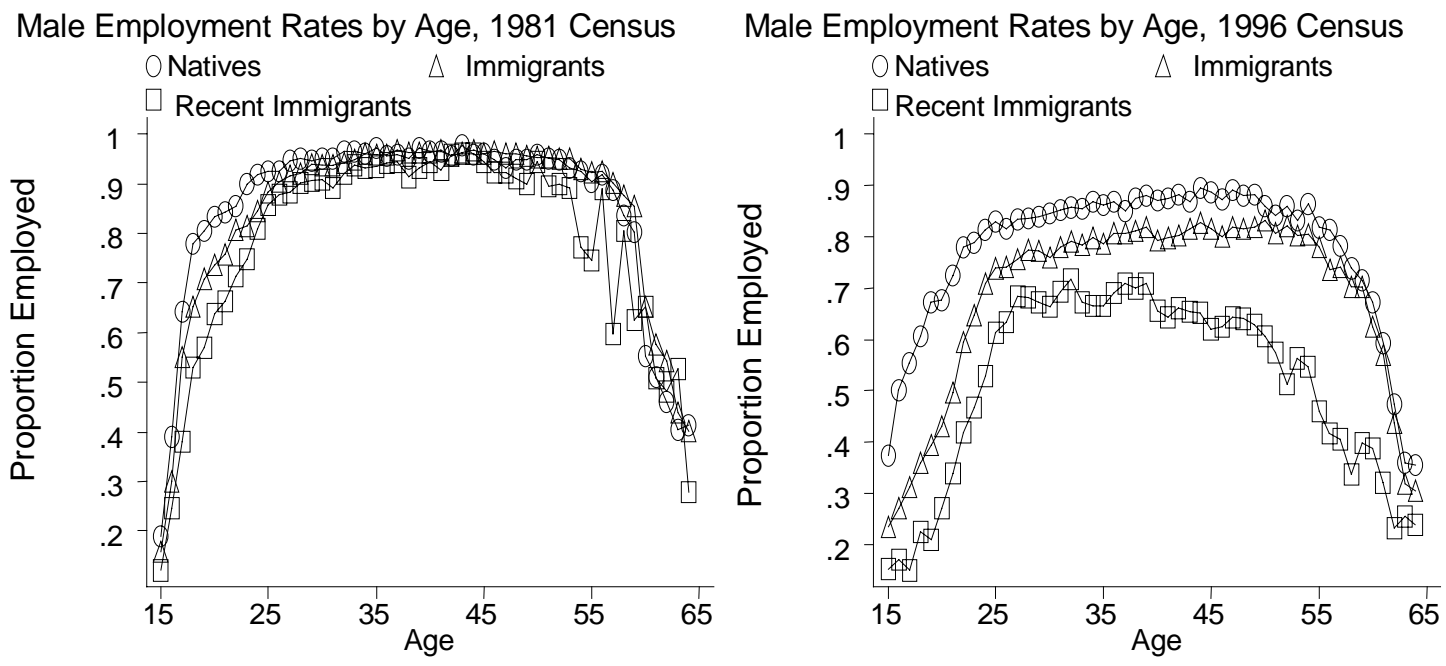

Female Employment Rates by Age, 1981 Census

Female Employment Rates by Age, 1996 Census
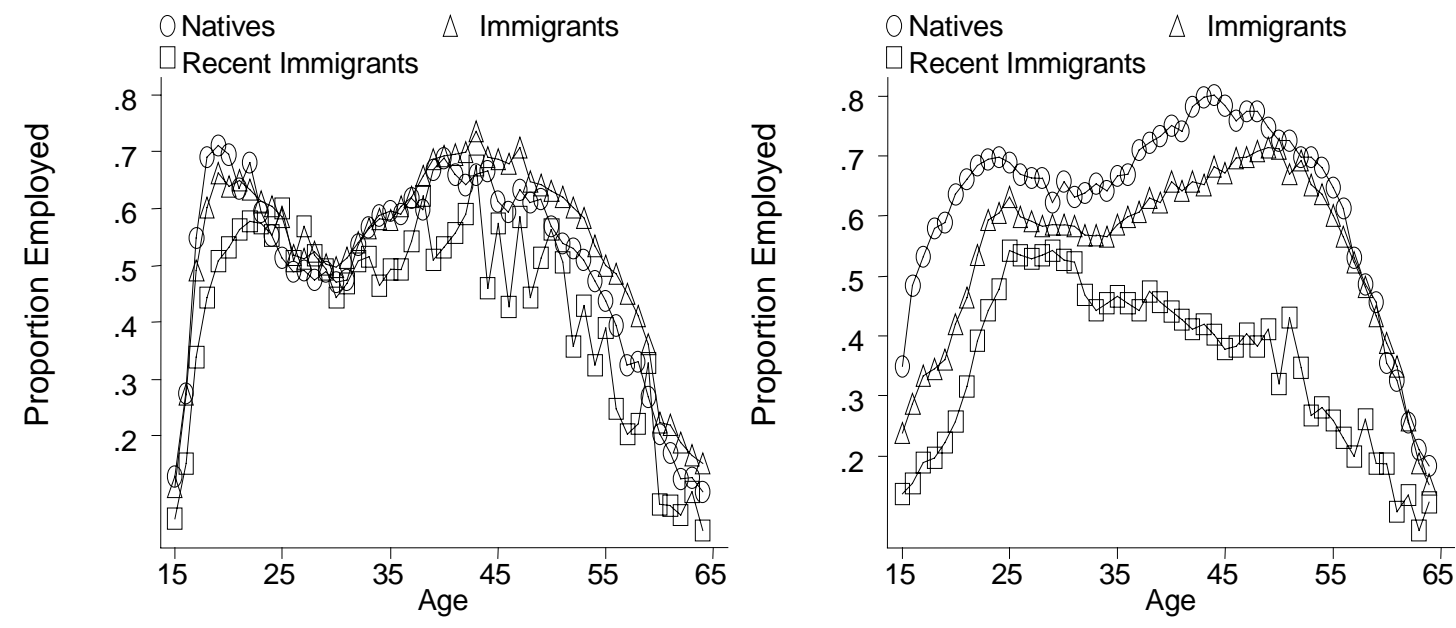

By 1996, the situation had changed considerably. Male employment had fallen below 90 percent for all groups and ages. However, the decline was much larger for recent immigrants, where employment rates did not reach 70 percent even among those aged 25 to 35 , and declined rapidly for older persons.

The female employment rates in the lower part of Figure 2 exhibit the typical "birth-dent" between the age of 25 and 35. Female employment tended to be lower than male employment in both in 1981 and 1996. However, convergence to the male levels took place for New Zealand-born women, as their employment rates increased between 
1981 and 1996. The opposite was the case for immigrant women, and as a consequence, the employment gap between immigrant and New Zealand-born women increased substantially. The declining relative performance of New Zealand's immigrants in the early 1990's was conspicuous. Possible explanations for this trend will be analysed below. First, however, it will be established that relative income followed a similar trend.

\subsection{Income and Social Benefits}

The forces that affected relative employment rates were likely at work for relative income as well. This is confirmed in Table 8. The first two columns give the unadjusted and adjusted relative incomes for employed residents in 1981 and 1996, respectively. The adjustment was based on a semi-logarithmic regression with log annual income as dependent variable and the independent variables hours of work (in the week prior to the Census), a polynomial in age, three indicator variables for highest qualification plus a dummy variable for immigrants. The reported adjusted relative income is obtained by taking the anti-log of the dummy coefficient. It provides a comparison of the incomes of immigrants and New Zealand-born workers who have otherwise similar characteristics. The adjustment is important as immigrants had relatively high levels of formal qualifications which renders a comparison with an "average" New Zealand-born worker of questionable value.

Table 8: Relative Income and Welfare Benefits, Immigrants and New Zealanders, 1981 and 1996

\begin{tabular}{lcccc}
\hline & \multicolumn{2}{c}{ Relative Income $^{\mathrm{a}}$} & \multicolumn{2}{c}{ Welfare Benefits $^{\mathrm{b}}$} \\
& \multicolumn{2}{c}{ (unadjusted/adjusted) } & & \\
& 1981 & 1996 & 1981 & 1996 \\
All Immigrants & $1.05 / 0.94$ & $0.99 / 0.89$ & 0.347 & 0.227 \\
Recent & $0.83 / 0.81$ & $0.84 / 0.75$ & 0.245 & 0.181 \\
Immigrants & & & & \\
New Zealanders & & & 0.343 & 0.259
\end{tabular}


Notes:

a Average nominal pre-tax total personal annual income from all sources. Grouped Census data were converted continuous income measure using midpoints. Relative to New Zealand-born persons.

$b \quad$ Proportion of Working Age Population Receiving Income from a Social Welfare Benefit at some time during the last 12 months prior to the Census.

This pattern is apparent in Table 8, where adjusted relative incomes of immigrants are always below the unadjusted ones. In 1981, for instance, an average immigrant's income was 5 percent above the income of an average New Zealand-born worker. In comparison to "similar" New Zealand-born workers, however, this advantage disappeared, and incomes were virtually identical on average. A similar adjustment effect was observed for recent immigrants in the two Census years who always had incomes below those of established immigrants. As for employment, the relative position of recent immigrants was worse in 1996 than it was fifteen years earlier.

One issue associated with the income levels of (recent) immigrants is the extent to which immigrants use welfare benefits. A disproportionate use of the welfare system is one of the ways in which immigration could adversely affect the well being of New Zealand-born persons. ${ }^{17}$ The available information only indicates whether or not a person has received at least one welfare benefit during the previous 12 months. ${ }^{18}$ It does not give the benefit duration or the benefit level. Table 8 shows that immigrants had about the same probability as New Zealand-born persons of having received at least one benefit payment. In 1996, the proportion of New Zealand-born persons who had received a benefit dropped to 26 percent, down from 38 percent in 1986; and to 23 percent, down from 37 percent in 1986, for immigrants. This drop was likely caused by the abolition of the universal family benefit on 1 October 1986. Recent immigrants

17 This is a highly simplified view. The real question is whether or not immigrants are net welfare recipients, i.e., whether they receive more welfare benefits than they contribute (through taxes or other payments) as a group over their lifetime.

18 The benefit definition is very inclusive and includes many partial benefits, such as childcare subsidies, and some "universal" benefits, such as the Family Benefit, which in 1981 was paid to all parents of children aged under 16 years. 
always were less likely than New Zealand-born persons to have received a benefit in all three Census years. ${ }^{19}$

\subsection{Region-of-Origin differences}

In sections 4.2-4.4 immigrants have been treated as a homogenous groups which they likely were not. In this section, the importance of region-of-origin differences will be highlighted. The following six regions are distinguished: UK\&Ireland, Australia, Europe\&Nth America, Pacific Islands, Asia and other countries. ${ }^{20}$ Although one could approach this issue in many ways, the particular focus here will be on trends in adjusted income differentials of employed recent immigrants. As shown in Winkelmann and Winkelmann (1998) the substantive result would not be affected if one were to look at other aspects of labour market outcomes.

Two questions can be addressed with the information on adjusted income differentials by region-of-origin that is provided in Table $9 .{ }^{21}$ First, how large were the differences between regions, and how did they change over time? From which sending countries came the more successful immigrants, and from which the less? And second, how much did the change in the composition of recent immigrants contribute to the declining fortunes of the "average" recent immigrant in New Zealand?

In 1981, adjusted log-income differentials ranged from -0.074 for recent UK and Irish immigrants to -0.270 for recent Asian immigrants, a gap of about 20 logpoints. The Pacific Islands, Asia, and Europe\&Nth America were grouped closely together. By 1996, the gap had almost tripled to 57 log-points. The same regions were

19 Immigrants are expected to have sufficient personal resources to maintain themselves and their dependents for at least the first 12 months of residence in New Zealand. During this period, they are not entitled to any income support benefits unless in severe financial hardship.

20 Winkelmann (2000) provides an analysis based on sub-regions within the Europe\&Nth America category.

21 As in the previous section, the adjustment controls for hours of work, age, age squared, qualification and gender. 
at the respective ends, and while the relative position of UK\&Irish immigrants relative to the New Zealand-born had improved, the opposite was the case for Asian immigrants.

Table 9: Adjusted income differentials and population shares of recent immigrants by region-of-origin, 1981 and 1996.

\begin{tabular}{lcccc}
\hline & $\begin{array}{c}\text { Differential } \\
\left(\operatorname{diff}_{81}\right)\end{array}$ & $\begin{array}{c}\text { Share } \\
\left(\mathrm{p}_{81}\right)\end{array}$ & $\begin{array}{c}\text { Differential } \\
\left(\operatorname{diff}_{96}\right)\end{array}$ & $\begin{array}{c}\text { Share } \\
\left(\mathrm{p}_{96}\right)\end{array}$ \\
UK \& Ireland & -.074 & 36.85 & .009 & 27.52 \\
Australia & -.175 & 16.14 & -.014 & 10.79 \\
Europe \& Nth America & -.262 & 15.07 & -.186 & 17.04 \\
Pacific Islands & -.233 & 14.62 & -.444 & 6.01 \\
Asia & -.270 & 13.10 & -.566 & 27.16 \\
Other countries & -.089 & 4.23 & -.216 & 11.48 \\
\hline
\end{tabular}

Note: Differentials and shares are for employed recent immigrants.

Concurrently, the share of Asian immigrants had increased from 13 percent of all recent employed immigrants in 1981 to 27 percent of all recent employed immigrants in $1996 .^{22}$ Both factors contributed to a decline in the estimated relative income of an average immigrant. However, the changes within-regions was quantitatively not as important as the changes in composition towards immigrants from Asia, as is shown by the following decomposition exercise: Let $p$ denote the proportion of employed immigrants from a specific region among all recent employed immigrants. The overall log-income differential between recent immigrants and New Zealand-born residents in a given year is simply the weighted average of the region specific logincome differentials, where the weights are provided by the proportions

22 The 1996 proportion of Asian recent immigrants among employed recent immigrants was much smaller than their overall share among all recent immigrants of 47 percent, as the Asian employment rate was very low. 
$\operatorname{diff}_{t}^{\text {Total }}={ }_{i=1}^{6} \operatorname{diff}_{i t} p_{i t}$

or, in vector notation, $\operatorname{diff}_{t}{ }^{\prime} p_{t}, t=81,96$. Moreover, the overall change can be computed as: ${ }^{23}$

$\operatorname{diff}_{96}{ }^{\prime} p_{96}-\operatorname{diff}_{81}{ }^{\prime} p_{81}=-0.236-(-0.168)=-0.068$

How much of this change is due to changes in composition, and how much to changes in region-specific differentials? Using the regression results, the change in the overall recent immigrant-New Zealand-born resident income differential can be decomposed as follows

$\operatorname{diff}_{96}{ }^{\prime} p_{96}-\operatorname{diff}_{81}{ }^{\prime} p_{81}=\operatorname{diff}_{96}{ }^{\prime}\left(p_{96^{-}} p_{81}\right)+p_{81}{ }^{\prime}\left(\operatorname{diff}_{96}-\operatorname{diff}_{81}\right)$

The first term on the right side gives the overall change caused by a change in composition, evaluated at the 1996 differentials. From Table 9, diff $96{ }^{\prime} p_{81}=-0.181$. Hence, the aggregate 1996 log-income differential would have amounted to -0.181 had the composition not changed between 1981 and 1996. The actual value was -0.236 , and the difference between the two, 0.055 percentage points, is the increase in the (recent) $\log$ income differential that is due to compositional changes. This constitutes about 80 percent of the total increase in the log-income differential. Alternatively, one could evaluate the change in composition using the 1981 differentials. The result is approximately the same.

The other twenty percent of the increase were associated with increases in the entry income differentials for recent immigrants from specific regions. We cannot tell from the data whether these changes were caused by changes in unobserved characteristics (either quantity or returns) within countries, or by the changes in the

\footnotetext{
23 Note that the overall differential differs from Table 8, as no frequency weights were used in the context of the Table 8 .
} 
receiving conditions in the New Zealand labour market that were mentioned at the beginning of section 4.4 .

\subsection{Evidence on Assimilation}

As suggested by the previous section, cohort effects, i.e. changing (adjusted) New Zealand-born - immigrants labour market differentials for successive immigrant cohorts at the time of arrival, were paramount. At the risk of being accused of oversimplification, the set of regions can be split into two categories: predominantly English speaking regions ("ESB": UK\&Ireland, Australia, and Europe\&Nth America) whose entry position (measured by the annual income for those in employment) improved over the last two decades ${ }^{24}$, and predominantly non-English speaking regions ("NESB": Asia and the Pacific Islands) whose entry position worsened. While the recent intake of immigrants from Asian and Pacific Island countries faced considerable initial problems, this issue is of less concern to policy makers and society if assimilation can be expected to be fast.

Using past data to predict the future assimilation of current arrivals obviously requires certain homogeneity assumptions. Winkelmann and Winkelmann (1998) follow the common approach in the literature by assuming that the entry position may differ between cohorts, but that their convergence path towards the position of New Zealandborn workers is stable over cohorts (See, for instance, Borjas, 1994). In particular, they estimated the parameters of the following model using pooled data from the three Census years 1981, 1986 and 1996:

$$
\log (\mathrm{y})=\alpha+\mathrm{X} \beta+{ }_{k=1}^{8} \eta_{k} C_{k}+\delta Y S M+\phi Y S M^{2}+\gamma Y E A R 86+\lambda Y E A R 96+\varepsilon
$$

where YSM stands for "years since migration" and $\mathrm{C}_{\mathrm{k}}, k=$ pre60, 61-65, 66-70, 71-75, 76-80, 81-85, 86-90, 91-95 denote succesive cohorts. $\eta_{k}$ measure the percentage difference in income between immigrants of cohort $k$ and otherwise similar New

24 To the point where certain immigrants groups actually "outperformed" similar New Zealand-born in terms of labour market outcomes independently of duration of residence. 
Zealand-born residents in the first year after arrival (for YSM=0), whereas $\delta$ and $\phi$ determine the rate of convergence. A typical income adjustment path for cohort $k$ would feature an initial income disadvantage upon entry $\left(\eta_{k}<0\right)$, combined with subsequently faster income growth for foreign-born workers $(\delta>0)$. $\delta$ literally measures the relative income growth attributable to the first year of residence. If, as expected, $\phi$ is negative, then relative income growth slows by $-2 \phi$ percentage points in each subsequent year, and income convergence occurs, if at all, after $\left(-\delta+\sqrt{\delta^{2}-4 \phi \eta_{k}}\right) / 2 \phi$ years. ${ }^{25}$ Moreover, the model can be generalised somewhat by interacting the qualification variables with both an immigrant dummy and the YSM polynomial. In this way, entry differentials between immigrants and New Zealand-born residents and convergence rates are allowed to vary by qualification levels.

Figure 3 summarises the predicted income position of hypothetical immigrants and New Zealand-born residents over the life cycle, based on the estimated regression coefficients. The figure displays separate profiles by English speaking background, sex, and education (school versus university). In all panels, the age at which the hypothetical immigrant entered New Zealand is set to 25. Both the immigrant and the New Zealandborn worker are followed from the age of 25 through to the age of 50. Finally, both are assumed to work full-time (40 hours per week) and immigrants' entry differentials are assumed to equal the (arithmetic) cohort average for the group. In this context, the $y$ axis gives the predicted log-income for a worker with the specified characteristics. Differentials over the life-cycle (moving along a profile) or differentials over groups (moving across profiles) can be interpreted as approximate measures of relative (percentage) income differentials.

25 Selective out-migration may distort this inference. If, on average, the less successful migrants leave, then the estimated convergence rates will overstate the true economic progress of those who stay (see, for instance, Borjas, 1994). 
Figure 3. Age-Log Income Profiles of Immigrants and New Zealand-born residents, by English Background and Sex.
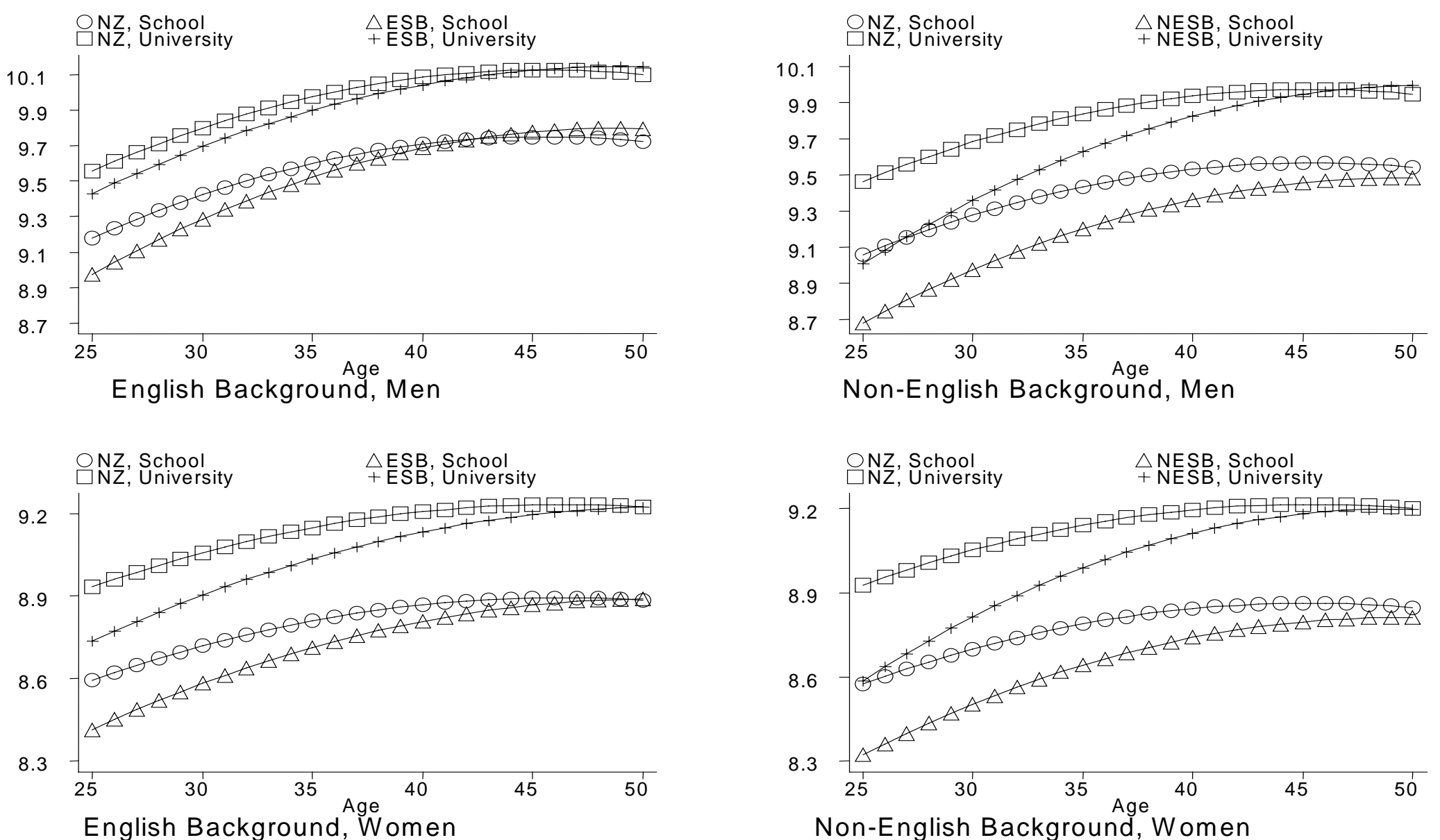

Non-English Background, Women 
For example, the upper left graph of Figure 3 shows the age-income profiles of male English background migrants. The vertical distance between the two qualification curves gives the percentage difference in income between school graduates and university graduates of a given age. Both New Zealand-born residents and immigrants had substantial returns to a university qualification, about 38 percent and (initially) about 46 percent, respectively. The vertical distance between the immigrant and New Zealand-born resident curves, for a given qualification level, gives the approximate percentage difference in income between immigrants and New Zealand-born residents. This vertical difference tended to decline with age and eventually disappeared, after about 18 years for school graduates and after about 20 years for university graduates. Hence, convergence was predicted to take place.

By allowing convergence profiles to differ by education level this analysis can shed light on the "skill transferability hypothesis". According to this hypothesis, immigrants face an initial disadvantage in the host labour market, relative to New Zealand-born residents with the same qualifications, because it takes time to generate credible information about the true value of the qualification, or, in the case of some professions, to obtain the required license. As a consequence, more highly qualified immigrants are likely to face a larger initial disadvantage than others, and also have faster subsequent convergence rates as the true value of their qualifications is revealed.

Figure 3 shows that this hypothesis appears not to be supported by the experience of English background male immigrants. To the contrary, less qualified ESB immigrants had a larger initial income disadvantage and faster subsequent adjustment rates. However, the transferability hypothesis is supported by the experience of non-English background immigrant men, depicted in the upper right panel of Figure 3, as more qualified Non-English background migrants had a substantially larger entry disadvantage but also faster subsequent income growth. The difficulty of NESB immigrants in making productive use of their qualifications upon arrival is illustrated by the low initial returns to a university qualification (relative to a school degree) of only 33 percent (compared to 46 percent for ESB migrants). 
As expected, the overall income differentials relative to New Zealand-born residents were much larger for NESB migrants than for ESB migrants. NESB migrants with university qualification are predicted to reach parity with similar New Zealand-born residents, although it will take about 20 years. NESB migrants with school qualification only are unlikely to reach New Zealand-born resident income levels within the time horizon of this analysis.

Are women different? The two lower panels of Figure 3 repeat the previous type of analysis for female immigrants. Female profiles tended to be flatter than male ones. There were two contributing factors. Firstly, female returns to experience were smaller (as were the returns to qualifications). Incomes of female New Zealand-born residents increased by 35 percent over the 25-year period, compared to an increase by 54 percent for males. Secondly, female immigrants had slower rates of convergence. The differences between ESB and NESB migrants were less pronounced than those for men, and convergence was achieved after about 25 years for ESB immigrants and NESB immigrants with university qualification.

To summarize, the results indicate that a typical immigrant entered with an income shortfall of about 20-30 percent relative to a similar New Zealand-born resident. This shortfall tended to disappear after 20-30 years of residence. Immigrants with English speaking background clearly "out-performed" non-English speaking background migrants.

\subsection{Effects on New Zealanders}

The limited research on the effects of immigration on New Zealand-born workers that has been undertaken so far has concentrated on macro-economic variables, in addition to some studies involving the housing market. For instance, Poot (1986) reports estimates from a dynamic model whereby the aggregate unemployment rate in $t$ is explained by its own lags and by a current and past values of an immigration variable, defined as net permanent and long-term migration as a proportion of the population size. Poot also takes into account that the causality may run the other way around. The general conclusion is that immigration has no strong short-run influence on 
macroeconomic variables but is itself highly endogenous and Granger-caused by macroeconomic conditions.

A lot of additional research, preferably based on micro-level data, will be required before a firmer picture on the wage and employment effects of immigration on skilled and unskilled New Zealand-born workers will emerge.

\section{Lessons for Europe}

Each country's main objective is to design its policies so as to improve its national welfare. One of the most contentious issues concerning immigration policy is how likely immigrants are to succeed in the domestic labor market: how much difficulty they have in finding employment and participating in the labor force, are their tax contributions likely to be higher than those of the natives, is their need for social assistance lower relative to that of the natives? The benefits of immigration to the host country are, in other words, more likely to be higher if immigrants fully realize their productive potential and perform relatively well in the labor market.

What, if any, is the lesson of New Zealand's immigration experience for European countries? Despite being located as far away from Europe as possible in terms of geography, New Zealand is arguably a country that has preserved closer cultural links with its European (here: British) ancestry than did Australia, Canada or the United States. At the same time, the current wave of immigrants from more heterogeneous source countries may lead to adjustment problems that resemble those experienced within Europe with respect to immigrants from North Africa or Eastern Europe.

A careful interpretation of the New Zealand experience suggests that a controlled immigration policy with an emphasis on skilled immigrants is no guarantee for success. New Zealand introduced a point system in 1991. The system was designed to select immigrants with qualifications and professional work experience. And indeed the skill levels of New Zealand's recent immigrants, measured in terms of formal qualifications, have further increased from a base level that was already 
relatively high before the 1991 policy changes, compared to the New Zealand born population.

It appears, however, that a formal qualification is no panacea against inferior labor market outcomes. The existing evidence suggests that recent immigrants from the Pacific Islands, and from Asia in particular, have employment rates and incomes that are substantially below those of New Zealand-born persons. The reasons for this situation are unclear, and may involve both demand factors, such as a structural change in the economy, or discrimination, and supply factors, such as insufficient language proficiency. 


\section{References}

Bedford, R. (1996) International Migration, 1995: Some Reflections on an Exceptional Year, New Zealand Journal of Geography, April, 21-33.

Borjas, G. (1994) The economics of immigration. Journal of Economic Literature, 32(4): 1667- 1717.

Brosnan, P. and J. Poot (1987) Modelling the determinants of Trans-Tasman migration after World War II, The Economic Record 63: 313-329.

Burke, K. (1986) Review of Immigration Policy, Appendix to the Journals of the House of Representatives 1986-87.

Chapple, S. and J. Yeabsley (1996) A framework for the assessment of the economic and social effects of immigration. NZIER report to the Department of Labour.

Chapple, S., S. Gorby and J. Yeabsley in collaboration with J. Poot (1994) Literature review on the economic impact of immigration, NZIER Working Paper No. 95/5, NZIER report to the Department of Labour.

Cook, L. (1997) New Zealand's current and future population dynamics, Paper presented at the Population Conference held in Wellington on 12-14 November 1997.

Dalziel, P. and R. Lattimore (1996) The New Zealand Macroeconomy. A Briefing on the Reforms, Auckland: Oxford University Press.

Gani, A. and B.D. Ward (1995) Migration of professionals from Fiji to New Zealand: A reduced form supply-demand model, World Development 23, 9, 1633-1637.

Gorby, S., D. James and J. Poot (1997) Population forecasting with endogenous international migration: the case of New Zealand, International Regional Science Review.

Maani, S. (1991) Consequences of current immigration in New Zealand: An economic overview. University of Auckland, Department of Economics Discussion Paper No. 87.

New Zealand Immigration Service (1995) A Review of New Zealand's Residence Policies: the "Targeted” Immigration Streams. Wellington. 
New Zealand Immigration Service (1997) New Zealand Immigration Policy and Trends, document prepared for the population conference, Wellington, 13-14 November 1997.

Poot, J. (1986) Immigration and the Economy: A Review of Recent Australian Findings on the Economic Consequences of Immigration and the Relevance of these Findings for New Zealand, Wellington: Institute of Policy Studies.

Poot, J. (1988a), "International Migration and the New Zealand Economy: A Trans-

Tasman Comparison", Baker, L. and Miller, P. (eds), The Economics of Immigration: Proceedings of a Conference, 22-23 April 1987, Canberra, Australian Government Printing Service.

Poot, J. (1988b), "The New Zealand Labour Force: A Demographic Outlook", Crothers, C. and Bedford, R. (eds), The Business of Population, Wellington, New Zealand Demographic Society.

Poot, J. (1993) Adaptation of migrants in the New Zealand labour market. International Migration Review, 27(1): 121-39.

Poot, J. (1998) The impact of immigration on labour markets and urban infrastructure in Australia and New Zealand, in: C. Gorter, P. Nijkamp and J. Poot (eds.) Crossing borders: Regional and urban perspectives on international migration, Avebury, Aldershot (in press).

Poot, J., G. Nana and B. Philpott (1988) International migration and the New Zealand economy: A long-run perspective. Wellington: Victoria University Press for the Institute of Policy Studies.

Shroff, G. (1988) New Zealand's immigration policy, New Zealand Official Yearbook 1988-89, 193-207.

Statistics New Zealand (1995) New Zealand Official Yearbook. Wellington.

Trlin, A. and P. Spoonley (1986) eds., New Zealand and International Migration. A Digest and Bibliography, Number 1. Department of Sociology, Massey University.

Trlin, A. and P. Spoonley (1992) eds., New Zealand and International Migration. A Digest and Bibliography, Number 2. Department of Sociology, Massey University. 
Trlin, A. and P. Spoonley (1997) eds., New Zealand and International Migration. A Digest and Bibliography, Number 3. Department of Sociology, Massey University.

Wearing, B. (1993) New Zealand's immigration policies and Immigration Act (1987): Comparisons with the United States of America, in: Ivan Light and Parminder Bhachu, Immigration and Entrepreneurship: Culture, Capital, and Ethnic Networks, Transaction: New Brunswick and London, 307 - 327.

Winkelmann, L. and R. Winkelmann (1997) Determining the relative labour force status of Maori and non-Maori using a multinominal logit model, Labour Market Bulletin, 1997(1): 24-62.

Winkelmann, L. and R. Winkelmann (1998) Immigrants in the New Zealand labour market: A study of their labour market outcomes, Wellington: New Zealand Department of Labour.

Winkelmann, L. and R. Winkelmann (1999) Immigrants in the New Zealand Labour Market: a Cohort Analysis using 1981, 1986 and 1996 Census Data, forthcoming in: Labour Market Bulletin 1991:1.

Winkelmann, R. (2000) The Labor Market Performance of European Immigrants in New Zealand in the 1980s and 1990s, forthcoming in: International Migration Review, Vol 34(1).

Zodgekar, A.V. (1997) Immigrants in New Zealand Society, Occasional Papers in Sociology and Social Policy, No 10, 1997, Victoria University of Wellington. 